\title{
Acute intravascular haemolysis and renal failure due to arsine poisoning
}

\author{
G. A. Coles \\ M.B., B.S. (Lond.), M.R.C.P. (Lond.) \\ Medical Registrar \\ H. J. DAVIES \\ M.B., B.S. (Lond.), D.P.H. (Lond.) \\ Her Majesty's Medical Inspector of Factories
}

\author{
D. DALEY* \\ M.B., B.Ch. (Wales), M.R.C.P. (Lond.) \\ Senior Medical Registrar \\ N. P. Mallick $†$ \\ B.Sc. (Manc.), M.B., Ch.B. (Manc.), M.R.C.P. (Lond.) \\ Research Fellow in Medicine
}

\author{
Medical Unit, Royal Infirmary, Cardiff, \\ Morriston Hospital, Swansea and Her Majesty's Medical Inspectorate \\ of Factories
}

\section{Summary}

Two men developed acute intravascular haemolysis after exposure to arsine gas in a metal smelting works. Both survived; one developed acute renal failure and required peritoneal dialysis. His renal function returned to near normal within 3 months. The probable mode of exposure has been investigated and is discussed. The toxic effects of arsine are briefly reviewed. The preventive action taken is detailed.

\section{Introduction}

Arsine poisoning has been recognized for over 150 years, the first known death being reported in 1815 (Hunter, 1962). We report two cases occurring simultaneously after accidental exposure to the gas in a metal smelting works. Both patients developed haemolytic anaemia and one acute renal failure which was treated by peritoneal dialysis.

\section{The process}

The patients, B.N. and J.B., were employed at a factory where zinc and lead are refined from the ore. The earlier stages of this process produce a mixture of molten lead and zinc.

After the separation of the two metals, the molten zinc is transferred to a final liquation (holding) chamber before casting into slabs. This transfer is made with a $1 \frac{1}{2}$-ton ladle and, at this point, sticks of metallic sodium are added to the ladle while it is

\footnotetext{
Correspondence to: Dr G. A. Coles, Medical Unit, Cardiff Royal Infirmary, Cardiff, Glam.

*Now Consultant Physician, Morriston Hospital, Swansea.

$\dagger$ Now Lecturer in Medicine, Medical Unit, Manchester Royal Infirmary.
}

being filled, to extract contaminant arsenic. The reaction produces sodium arsenate which is removed along with other drosses from the top of the ladle. To make the removal easier, sawdust is stirred in to 'dry off' the dross. Following the sodium treatment only trace quantities of arsenic are left in the molten zinc when it is passed into the liquation chamber.

\section{The exposure}

The liquation chamber needs cleaning at intervals and the two men, B.N. and J.B., were doing this work at the time of their exposure to arsine. The normal procedure for cleaning the chamber is to drain off the molten metal, open all cleaning doors and then to blow air into the chamber until cool enough for men to enter.

At first as much cleaning as possible is done from outside using pneumatic tools with long bars. Later men enter the chamber wearing dust respirators. The cleaning operation on this occasion lasted about 7 days, during which the inside of the chamber was hosed down several times with water from outside to lay the dust. Before entering the chamber the men wait several minutes for the water vapour to disperse.

On the day of the accident much of the chamber had already been cleaned and the two men were sent to finish the job. The hose was not available to them so they took buckets of water into the virtually enclosed liquation chamber and splashed it about to settle the dust. Within $1 \mathrm{hr}$ B.N. felt ill and went home, where he vomited and passed red urine. He developed generalized aching and shivering and was jaundiced within 24 hr. J.B. did not develop symptoms for $24 \mathrm{hr}$. 


\section{Case records}

Patient No. 1

B.N. was admitted to Hill House Hospital on 28 April 1966, $40 \mathrm{hr}$ after exposure, where it was found that there was methaemalbuminaemia and haemoglobinuria. He was transferred to Swansea General Hospital for further investigation. The blood urea was $300 \mathrm{mg} / 100 \mathrm{ml}$ and as he had passed no urine since his first admission to hospital he was referred to the Medical Unit at Cardiff Royal Infirmary. On admission there he was drowsy and retching. There was generalized coffee brown pigmentation. The conjunctivae were icteric and the mucosae pale. There was epigastric tenderness and the liver was just palpable.

Investigations: $\mathrm{Hb} 49 \%$, reticulocytes $5 \%$, WBC $24,000 / \mathrm{mm}^{3}$ (polymorphs $71 \%$ ), platelets $132,000 /$ $\mathrm{mm}^{3}$. Film: Normochromic, normocytic anaemia with no spherocytes, fragmented cells or punctate basophilia. Methaemoglobin and methaemalbumin present in serum. Blood urea $373 \mathrm{mg} / 100 \mathrm{ml}$, serum $\mathrm{Na} 130, \mathrm{~K} \mathrm{4} \cdot 6, \mathrm{Cl} 93, \mathrm{HCO}_{3} 14 \mathrm{mEq} / \mathrm{l}$. Serum bilirubin $1.9 \mathrm{mg} / 100 \mathrm{ml}$, (but colour change obscured by the $\mathrm{Hb}$ in serum). SGOT 136 units. SGPT 50 units. Chest X-ray normal. Abdominal X-ray showed kidneys normal in size and outline. ECG normal. There was no urine for analysis.

Progress: The patient was given $40 \mathrm{~g}$ mannitol intravenously without increase in urinary output. Peritoneal dialysis was started and repeated as necessary. He was anuric for 7 days, and did not pass more than $50 \mathrm{ml} /$ day for a further 2 weeks, after which there was a diuresis. Anaemia was treated initially with 2 units of concentrated RBCs: the haemoglobin then remained at 50-60\% throughout his illness. By 10 May 1966 methaemalbumin and methaemoglobin were no longer detectable in the serum and there was no jaundice. He was discharged after 6 weeks in hospital. Blood urea was $93 \mathrm{mg} /$ $100 \mathrm{ml}$, inulin clearance was $20 \mathrm{ml} / \mathrm{min}$. One month later creatinine clearance was $70 \mathrm{ml} / \mathrm{min}$; blood urea $36 \mathrm{mg} / 100 \mathrm{ml} ; \mathrm{Hb} \mathrm{78 \%}$; liver function tests normal. Three months after discharge the $\mathrm{Hb}$ was $97 \%$ and there was no urine deposit. He has since returned to work.

\section{Patient No. 2}

Twenty-four hours after exposure J.B. had epigastric pain made worse by eating, and passed red urine. Within $48 \mathrm{hr}$ he had become jaundiced and was admitted to Morriston Hospital, Swansea on 29 April 1966. On admission he was obviously jaundiced and had a fever of $99 \cdot 4^{\circ} \mathrm{F}$. The liver was just palpable and was tender.

Investigations: $\mathrm{Hb} 75 \%, \quad \mathrm{WBC} \quad 10,200 / \mathrm{mm}^{3}$ (polymorphs $89 \%$ ), platelets $124,000 / \mathrm{mm}^{3}$. Blood urea $35 \mathrm{mg} / 100 \mathrm{ml}$, serum electrolytes normal, bilirubin $3.7 \mathrm{mg} / 100 \mathrm{ml}$, serum haptoglobins nil. Faecal urobilinogen $387 \mathrm{mg} / 24 \mathrm{hr}$ (normal 30-250). Urine contained protein, RBC, WBC and granular casts.

Progress: The patient had not been oliguric, but it was decided to give mannitol $40 \mathrm{~g}$, i.v. There was a good diuresis and no more mannitol was given. The highest blood urea was $44 \mathrm{mg} / 100 \mathrm{ml}$ and the lowest $\mathrm{Hb} 64 \%$. His condition improved steadily without further treatment and he was discharged on 20 May 1966 when the blood urea was $30 \mathrm{mg} / 100 \mathrm{ml}$ and the $\mathrm{Hb}$ was $76 \%$. Six weeks later he was back at work. Physical examination was normal and the $\mathrm{Hb}$ was $111 \%$. There was no urine deposit.

\section{Discussion}

The reasons why arsine can be produced in industrial processes, often unexpectedly, have been reviewed by Buchanan (1962). He reports the lessknown reaction in which (nascent) hydrogen may be generated between certain light metals and a strong alkali. Zinc is quoted as one light metal which will bring about such a reaction especially with the aid of heat. The action of the nascent hydrogen upon arsenic could result in the formation of arsine.

In this incident it is more likely that arsine was generated by the hydrolysis of sodium arsenide which had collected in the zinc liquation chamber over weeks of operation. The arsenide could have been formed by the action of heat on sodium arsenate.

\section{The toxicity of arsine}

Arsine is an extremely toxic gas (Doig, 1958). It produces a characteristic illness which was at once recognized in these two cases. Concentrations of 3-10 ppm will produce slight symptoms after several hours exposure, and concentrations of $16-30 \mathrm{ppm}$ are dangerous after $\frac{1}{2}-1 \mathrm{hr}$.

Arsine inhibits tissue oxidation and particularly affects the erythrocytes, causing rapid intravascular haemolysis (Kensler, Abels \& Rhoads, 1946). The renal lesion appears to be acute tubular necrosis secondary to this haemolysis.

The mortality of arsine poisoning in the reported cases is $22 \%$ (Buchanan, 1962) and in the older literature there are no reports of patients surviving if renal failure developed. However, haemodialysis and peritoneal dialysis have altered the prognosis (Ullrich, 1958; Neuwirtova et al., 1961 ; Derot et al., 1963). It is clear from our patient, B.N., that there may be good recovery of renal function.

Mannitol was given to both our patients but a response could not be expected so long after the initial exposure to arsine and the development of haemolysis. BAL therapy is said to be ineffective in 
arsine poisoning and this is not surprising since only very small concentrations of the gas are required to produce a toxic effect (Vallee, Ulmer \& Wacher, 1960). There is experimental evidence that 2,3dimercaptopropyl ethyl ether may protect against arsine poisoning if given within $12 \mathrm{hr}$ of exposure (Kensler et al., 1946) but we know of no clinical report of its use.

\section{Preventive action}

Since arsenic is an impurity in the raw ore it has to be accepted that the aggregation of trace quantities of metallic arsenides cannot be prevented in this process of zinc purification and a build-up of the arsenides will occur in the dust and debris of the zinc liquation chamber.

This presents the serious potential hazard of accidental production of arsine and every effort will be made in future to prevent the wetting, or even moistening, of the dust and debris in the essential cleaning process. All men exposed to the dust will wear dust masks whilst those who climb into the chamber for the actual cleaning will wear airline respirators. The roof of the liquation chamber will be removed during cleaning and the chamber exposed to atmosphere so that any arsine that is given off by mischance will be diluted.

Disposal of the debris will be controlled; ultimately the dust will be soaked with water so that any arsenide remaining is converted to arsine under safe conditions.

\section{Acknowledgments}

We would like to thank Professor $H$. Scarborough and Dr E. A. Danino for allowing us to publish details of these patients who were under their care. We would also like to acknowledge Professor Scarborough for his helpful criticisms and the assistance of the management of the factory in preparing this report.

\section{References}

Buchan, W.D. (1962) Toxicity of Arsenic Compounds. Elsevier, Amsterdam.

Derot, M., Legrain, M., Jacobs, C., Prunier, P. \& Hazebrouce, G. (1963) Poisoning due to arseniuretted hydrogen. Study of renal forms apropos of group poisoning (5 cases). J. Urol. Nephrol. 69, 407.

DoIG, A.T. (1958) Arseniuretted hydrogen poisoning in tank cleaners. Lancet, ii, 88.

HUNTER, D. (1962) The Diseases of Occupations, 3rd edn, p. 335. English Universities Press, London.

Kensler, C.J., Abels, J.C. \& RhOADS, C.P. (1946) Arsine poisoning, mode of action and treatment. J. Pharmacol. exp. Ther. 88, 99.

Neuwirtova, R., Chytil, M., Valek, A., Davin, S. \& VALACH, V. (1961) Acute renal failure following an occupational intoxication with arsine $\left(\mathrm{AsH}_{3}\right)$ treated by the artificial kidney. Acta med. scand. 170, 535.

UlLRICH, G. (1958) Course and treatment of an acute toxic renal insufficiency after arsine poisoning. Wien. klin. Wschr. 70, 538.

VALLEE, B.L., Ulmer, D.D. \& WACHER, W.E. (1960) Arsenic toxicology and biochemistry. Arch. Ind. Hyg. 21, 132. 